Elif Ulu, İlhan Yaylım*, Soykan Arıkan and Canan Cacına*

\title{
The evaluation of PIK3CA gene variation and serum PI3K level in breast cancer risk and prognosis in Turkish population
}

\section{[Meme kanseri risk ve prognozunda PIK3CA gen varyasyonu ve serum $\mathrm{PI} 3 \mathrm{~K}$ düzeyinin Türk toplumunda değerlendirilmesi]}

https://doi.org/10.1515/tjb-2021-0072

Received March 31, 2021; accepted September 30, 2021; published online November 29, 2021

\section{Abstract}

Objectives: The PI3K (Phosphatidylinositol 3-kinase) is the member of lipid kinase family that plays important roles in tumorigenesis, cancer development and cell proliferation. In our study, we aimed to investigate the relationships between breast cancer risk and prognosis with PIK3CA rs6443624 (C>A) intron region gene polymorphism and serum PI3K levels.

Methods: A total of 61-patients with breast cancer and 101 controls were included to the study. PIK3CA polymorphism was detected by Polymerase Chain Reaction-Restriction Fragment Length Polymorphism (PCR-RFLP) technique. Serum PI3K levels were measured by Enzyme-Linked Immuno Sorbent Assay (ELISA).

\footnotetext{
*Corresponding authors: Dr. İlhan Yaylım and Asst. Prof. Dr. Canan Cacına, Professor, Department of Molecular Medicine, Aziz Sancar Institute of Experimental Medicine, Istanbul University, ÇapaIstanbul, Istanbul, Turkey, Phone: +90 2124142000 33326, Fax: +90 212542 4171, E-mail: ilhanyaylim@gmail.com (i. Yaylım), canan.cacina@istanbul.edu.tr (C. Cacına). https://orcid.org/00000001-8998-2028 (i. Yaylım). https://orcid.org/0000-0001-7911-4390 (C. Cacına)

Elif Ulu, Department of Molecular Medicine, Aziz Sancar Institute of Experimental Medicine, Istanbul University, Istanbul, Turkey. https:// orcid.org/0000-0002-5167-588X

Soykan Arıkan, General Surgery Clinics, Istanbul Education and Research Hospital, Istanbul, Turkey. https://orcid.org/0000-00017132-6161
}

Results: PIK3CA $(\mathrm{C}>\mathrm{A})$ gene polymorphism genotype and allele distributions were no significant in cases and controls ( $\mathrm{p}>0.05)$. The serum PI3K levels of breast cancer patients were found significantly higher than the control groups $(\mathrm{p}=0.033)$. There were not significant association between PIK3CA $(\mathrm{C}>\mathrm{A})$ gene polymorphism and clinic and prognostic parameters in our study group. We also evaluated serum PI3K levels in the term of tumor progression, but we did not observe any significant data.

Conclusions: We suggest that serum PI3K levels may play role in breast cancer risk and larger patient groups may have clinical value in assessment of the genetic risk and tumor progression of breast cancer.

Keywords: apoptosis; breast cancer; phosphatidylinositol4,5-bisphosphate 3-kinase catalytic subunit alpha (PIK3CA); serum level; single nucleotide polymorphism (SNP).

öz

Amaç: PI3K (Fosfatidilinozitol 3-kinaz); tümör gelişimi, kanser ve hücre proliferasyonunda önemli rol oynayan lipid kinaz ailesinin üyesidir. Bu çalışmada, PIK3CA rs6443624 (C>A) gen polimorfizmi ve serum PI3K düzeylerinin meme kanseri risk ve prognozundaki etkilerinin araştırılması amaçlanmıştır.

Gereç ve Yöntem: Çalışmamıza 61-meme kanserli hasta ve herhangi bir benign veya malign tümörü olmayan 101-kontrol bireyi dahil edilmiştir. Polimeraz Zincir Reaksiyon- Restriksiyon Parça Uzunluk Polimorfizmi (PCR-RFLP) tekniği ile PIK3CA polimorfizmi, ve Enzim Bağlı İmmünosorbent analizi (ELISA) ile serum PI3K seviyeleri belirlenmiştir.

Bulgular: Çalışmamız sonucunda PIK3CA $(\mathrm{C}>\mathrm{A})$ gen polimorfizm genotipi ve allel dağılımları açısından hasta ve 
kontrol grubu arasında anlamlılık saptanmamıştır ( $>0.05$ ). Meme kanseri hastalarının, serum PI3K düzeyleri kontrol gruplarına göre anlamlı olarak yüksek oranda tespit edilmiştir $(\mathrm{p}=0.033)$. Çalışma grubumuzda PIK3CA $(\mathrm{C}>\mathrm{A})$ gen polimorfizmi, serum PI3K düzeyleri ile klinik ve prognostik parametreler arasında anlamlı bir ilişki gözlenmemiştir.

Sonuç: Araştırmamız sonucunda serum PI3K düzeylerinin, meme kanseri riskinde rol oynayabileceğini ve meme kanserinin genetik risk ve tümör ilerlemesinin değerlendirilmesinde daha büyük hasta gruplarında klinik değeri olabileceğini düşünmekteyiz.

Anahtar Kelimeler: apoptoz; Meme kanseri; Fosfatidilinozitol-4,5-bifosfat 3-kinaz katalitik alt birim alfa (PIK3CA); serum düzeyi; tek nükleotid polimorfizmi (SNP).

\section{Introduction}

Breast cancer (BC) underlying mechanism is related with various growth factors and receptors that activate cell proliferation and it is also known as the most common malignant tumor that causes death among women [1]. It has been reported that many signaling pathways and their interactions also dysregulation in their functions play a key role in the progression of BC [2-5]. Phosphatidylinositol 3-kinases (PI3Ks) are family of intracellular lipid kinases phosphorylate the 3'-hydroxyl group of phosphatidylinositols and phosphoinositides that regulate many cellular processes including protein synthesis, cell survival, proliferation, differentiation, angiogenesis and apoptosis [3-9]. Furthermore (PI3Ks) pathway is one of the most frequently disrupted mechanisms in human cancers and shown to be responsible for resistance to anticancer therapies by provoking tumor development [3-9]. To our best knowledge PI3K isoforms induce the signal transduction trafficking that activated by cell surface receptors including receptor tyrosine kinases (RTKs) and G-protein-coupled receptors (GPCRs) and trigger other effector pathways such as serine/threonine kinase $A K T$ and mammalian target of rapamycin (mTOR) [7-11]. Tumor suppressor PTEN (The Phosphatase and Tensin homolog deleted on chromosome 10) which is a negative regulator of the PI3K/AKT pathway, acts as an antagonist of the PI3K effects [12]. It has been previously reported that the loss of PTEN functions may cause excessive activation of the PI3K pathway and consequently promote cell proliferation [9, 13].

There is a broadening characterization for each of the three categories PI3K classes (I, II and III) and further level of their complexity is related with eight PI3K isoforms $[14,15]$. Previous studies reported that Class I; PI3Ks primarily phosphorylate phosphatidylinositol-4,5-bisphosphate (PIP2) to generate the lipid second messenger phosphatidylinositol-3,4,5-trisphosphate (PIP3) and they are related with (RTKs) and (GPCRs) thus they play important roles in several pathways such as metabolism, proliferation, autophagy, chemotaxis also described as the prominent class that associated with cancer [9-11, 16-18]. PI3K; Class I members are heterodimeric molecules consist of catalytic and regulatory subunit and activated through the inhibitory action of the p85 subunit on the p110 catalytic subunit (or p110 $\alpha$ protein) $[11,19,20]$. p110 alpha $(\mathrm{p} 110 \alpha)$ protein is a member of Class IA; PI3K and it was known encoded by the PIK3CA gene [21].

It has been that reported breast cancer tumorigenesis is closely related with PI3K pathway due to the majority of cases of this disease harbor at least one molecular mechanism that potentially enhances the pathway [22]. Further scientific advances have led to the discovery novel biomarkers associated with $\mathrm{BC}$ risk and prognosis and these mutations of PI3K specifically PIK3CA gene mutations have the potential to become a clinically useful biomarkers, because they are located on the important signaling pathway related with several biological molecules and found at high frequency also easy to measure (present or absent) [22-26].

PIK3CA gene is $34 \mathrm{~kb}$ length and located in the $3 \mathrm{q} 26.3$ chromosome region, it has 20 exons, encodes 1,068 amino acids [19, 21]. Somatic missense mutations and polymorphisms have been identified along the PIK3CA gene p110 $\alpha$ sequence [24-27]. PIK3CA; rs6443624 (C>A) gene polymorphism is located in intron region [27]. Although the effects of several PIK3CA polymorphisms have been investigated in different types of malignancy $[27,28]$ there are limited number of studies that subjected directly rs6443624 gene variation in the literature. The available literatures regarding the significance of PIK3CA rs6443624 report conflicting results $[27,28]$. In several studies researchers suggested that variation might affect the binding of transcription factors and change the splicing patterns or transcription of the PIK3CA gene while other group of researchers reported PIK3CA rs6443624 variation could be an independent predictor and prognostic factor [27, 28]. However studies concluded that the association between PIK3CA rs6443624 and BC risk and patient survival remains still unclear $[27,28]$.

Several analysis that related with PIK3CA gene mutations and polymorphisms have been conducted in different populations [26-28] but we did not observe directly associated data with PIK3CA rs6443624 gene variation and serum PI3K levels in Turkish population. In this purpose, the present study was designed to investigate the possible 
relationship between the PIK3CA rs6443624 genetic variation and serum PI3K expression in $\mathrm{BC}$ risk and prognosis.

\section{Materials and methods}

\author{
Study design
}

This case control study was approved by the Istanbul University Faculty of Medicine Ethics Committee [Project No. 35782]. The clinical and histopathological evaluations of 61 breast cancer patients were performed by the Istanbul Education and Research Hospital General Surgery Clinic. The control group consists of 101 healthy individuals with no signs of malignancy and preferably no family history of cancer. We used the Power and Sample Size Program software to calculate power and the effective sample size. The study protocol was consistent with the World Medical Association Declaration of Helsinki (Ethical Principles for Medical Research Involving Human Subjects). After obtaining informed consent, the blood specimens were collected from the patients before any treatment had been started (chemotherapy or radiotherapy). Data on age, family history, smoking status and alcohol consumption were obtained from the study questionnaire and classified in cases and control groups. Histological grade for individual tumors was determined through the assessment of differentiation. Questionnaires, medical records, and pathological reports were received to confirm the diagnosis and cancer status.

\section{Polymorphism analysis}

Genomic DNA was obtained from $10 \mathrm{~mL}$ of fresh peripheral blood samples which collected in EDTA tubes and extracted by salt out precipitation method based on isolation of leukocytes from anticoagulated blood, digestion with proteinase $\mathrm{K}\left[29\right.$ ] and stored at $-80^{\circ} \mathrm{C}$ until assayed. To assess quantity and quality of DNA, we measured samples at $260 / 280 \mathrm{~nm}$ ratio absorbance spectrum by using the Thermo Scientific NanoDrop ND 1000 Spectrophotometer (Thermo Fisher Scientific Inc.). The PIK3CA rs6443624 (C>A) polymorphism genotyping was performed by polymerase chain reaction (PCR) and restriction fragment length analysis (RFLP) methods. Rigorous quality control procedures were applied throughout the genotyping process. Reagents for PCR were carefully aliquoted, and each aliquot was used no more than three times to avoid contamination. A negative control (no DNA template) was added to monitor PCR contamination for each assay. Approximately $10-15 \%$ of the samples in each genotype group were randomly selected for repeated assays by PCR following RFLP. A 355 bp PCR product of the gene was amplified by using Forward 5'-TAAGATGTGCAGAGTTCGTTGTATG-3' and Reverse 5'-TTGCCTTTGTAAATATGCTCCATAATC- $3^{\prime}$ primers [30]. The reaction mixture was prepared as 12.9 $\mu \mathrm{L}$ distilled water, $3 \mu \mathrm{L} 10 \times$ PCR Buffer, $1.2 \mu \mathrm{L} \mathrm{MgCl}_{2}$, $3 \mu \mathrm{L}$ dNTP, $1.2 \mu \mathrm{L}$ from each primer and $0.5 \mathrm{U}$ Taq polymerase (i-StarTaq ${ }^{\mathrm{TM}}$ DNA Polymerase, Korea). $23 \mu \mathrm{L}$ of reaction mix was dispensed into the PCR tubes as the number of samples. Afterwards $2 \mu \mathrm{L}$ of DNA, $50-100 \mathrm{ng}$, was added to each tube immediately and the reaction volume reached $25 \mu \mathrm{L}$. The PCR reactions were started with an initial denaturation the DNA at $95^{\circ} \mathrm{C}$ for $5 \mathrm{~min}$, followed by 35 cycles at $94^{\circ} \mathrm{C}$ for $45 \mathrm{~s}, 60^{\circ} \mathrm{C}$ for $45 \mathrm{~s}, 72^{\circ} \mathrm{C}$ for $45 \mathrm{~s}$; the final extension step was at $72^{\circ} \mathrm{C}$ for $4 \mathrm{~min}$. The PCR products were digested with AluI restriction enzyme (Thermo Fisher Scientific ${ }^{\mathrm{TM}}$, Vilnius, Lithuania) overnight at $37^{\circ} \mathrm{C}$ and analyzed on $2 \%$ agarose gel containing ethidium bromide. After the digestion by the restriction enzyme, the homozygous CC genotype produced two fragments $(26,293 \mathrm{bp})$, heterozygous CA genotype produced three fragments (355,262 and $93 \mathrm{bp})$ and the AA genotype produced one fragments (355 bp) [30] (Figure 1).

\section{PI3K assay}

Peripheral blood samples of 43 patients and 62 control groups were collected in serum-separating tubes without anticoagulant. The samples were centrifuged at $10,062 \times g$ for $5 \mathrm{~min}$ for individual serum collection. The eluted sera were aliquoted into portions and preserved at $-80^{\circ} \mathrm{C}$ until analysis under laboratory conditions. Serum PI3K levels were determined with the Sandwich Enzyme-Linked Immuno Sorbent Assay (ELISA) kit (SunRed, China, Cat No. 201-12-0897, Lot No. 201910). Reference ranges for PI3K were $0.25-70 \mathrm{ng} / \mathrm{mL}$.

\section{Statistical analysis}

All statistical analyzes were performed using the SPSS (version 15.0 SPSS Inc., Chicago, IL, USA) software package. Data are expressed as means \pm SD. Categorical data were evaluated with Student's t-test, and chi-square $\left(\chi^{2}\right)$. The differences in the distribution of PIK3CA rs6443624 (C>A) polymorphism genotypes or alleles between cases and controls were tested using the chi-square $\left(\chi^{2}\right)$ test. Significance was accepted as $\mathrm{p}<0.05$. Hardy-Weinberg (HWE) balance was checked with the chisquare test. The genotype frequency distribution was consistent with the Hardy-Weinberg Equilibrium in control group ( $p>0.05$ ). Odds ratios (ORs) and 95\% confidence intervals (95\% CI) were calculated to estimate breast cancer risk. Student's t-test or ANOVA and tests based on data distribution with Mann-Whitney U or Kruskal-Wallis tests were used to assess both the prevalence of the genotype and allele frequencies and the levels of PI3K between groups.

\section{Results}

A total of 61 breast cancer cases and 101 healthy controls were included in the current study. All participants were female. Characteristics of patients with BC and healthy control groups are shown in (Table 1). The mean age of BC cases were $47.53 \pm 12$ years and the mean age of 101 healthy individuals were $44 \pm 9.49$ years. There were no significant differences in the distribution of age $(\mathrm{p}=0.183)$, family history $(\mathrm{p}=1.00)$, smoking status $(\mathrm{p}=1.00)$ among the studied groups. We evaluated the cases in terms of tumor type, invasive ductal carcinomas were observed with a rate of $82.6 \%$ and other classifications (in situ ductal and mucinous) in $17.3 \%$ of $\mathrm{BC}$ cases. The tumor stage rates were determined as $29.2 \% \mathrm{~T} 1,41.7 \% \mathrm{~T} 2,12.5 \% \mathrm{~T} 3$ and $16.7 \% \mathrm{~T} 4$. Also, we observed that the $63.6 \%$ of cases were in premenopausal and $36.4 \%$ were in postmenopausal period. 


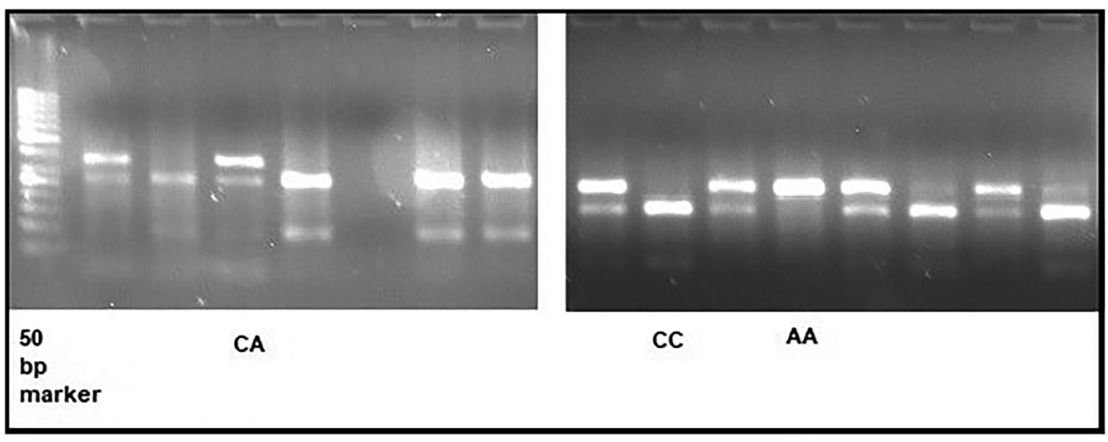

Figure 1: Agarose gel electrophoresis images of the PIK3CA ( $>A)$ fragments.
When our study group was evaluated by the terms of genotype distribution, the PIK3CA rs6443624 (CC, CA and AA) genotypes frequencies were detected as (47.5, 45.5, 6.9; 59, 39.3, and 1.6\%) in controls and patients groups, respectively. We did not observe statistically significant

Table 1: Clinical features of control individuals and $B C$ cases (\%).

\begin{tabular}{|c|c|c|}
\hline & Controls $(n=101)$ & Cases $(n=61)$ \\
\hline Mean \pm SD age, years & $44 \pm 9.49$ & $47.53 \pm 12.56$ \\
\hline \multicolumn{3}{|l|}{$p>0.05$} \\
\hline \multicolumn{3}{|l|}{ Smoking status } \\
\hline Smoker & 0 & 8.3 \\
\hline Non smoker & 100 & 91.7 \\
\hline \multicolumn{3}{|l|}{$p>0.05$} \\
\hline \multicolumn{3}{|l|}{ Family history of cancer } \\
\hline Yes & 0 & 33.3 \\
\hline No & 100 & 66.7 \\
\hline \multicolumn{3}{|l|}{$p>0.05$} \\
\hline \multicolumn{3}{|l|}{ Tumor stage } \\
\hline $\mathrm{T} 1$ and $\mathrm{T} 2$ & & 70.8 \\
\hline T3 and T4 & & 29.2 \\
\hline \multicolumn{3}{|l|}{ Lymph node status } \\
\hline NO & & 42.9 \\
\hline $\mathrm{N}+$ & & 57.1 \\
\hline \multicolumn{3}{|l|}{ Histopathology } \\
\hline İnvasive ductal & & 82.6 \\
\hline İn situ ductal & & 4.3 \\
\hline Mucinous & & 13.0 \\
\hline \multicolumn{3}{|l|}{ Distant metastasis } \\
\hline$(+)$ & & 27.0 \\
\hline$(-)$ & & 73.0 \\
\hline \multicolumn{3}{|l|}{ Menopausal status } \\
\hline Premenopause & & 63.6 \\
\hline Postmenopause & & 36.4 \\
\hline \multicolumn{3}{|l|}{ ER status } \\
\hline Negative & & 9.1 \\
\hline Positive & & 90.9 \\
\hline \multicolumn{3}{|l|}{ PR status } \\
\hline Negative & & 22.2 \\
\hline Positive & & 77.8 \\
\hline \multicolumn{3}{|l|}{ cerb B } \\
\hline$(-)$ & & 72.4 \\
\hline$(+++)$ & & 27.6 \\
\hline
\end{tabular}

differences between the two groups in terms of the genotype distribution and allele frequency (Table 2). In addition, the PIK3CA $(C>A)$; alleles frequencies were analyzed according to the histopathological features of breast cancer patients such as tumor stage, presence of nodal metastasis, distant metastasis, estrogen receptor, progesterone receptor, tumor necrosis. We couldn't find any significant relationship between the allele frequency and these prognostic parameters ( $p>0.05$ ) (Table 3).

We also evaluated the serum PI3K levels in our study groups and found that the mean serum levels of the cases were significantly increased $(1.188 \pm 0.743)$ compared to 62 the control groups $(0.910 \pm 0.574)(\mathrm{p}=0.033)$ (Table 4). Furthermore we investigated the possible association between PIK3CA (C>A); CC, CA, AA genotypes and serum PI3K levels in cases and control groups but there were no significant relation between PIK3CA polymorphism genotype distribution and serum PI3K levels (data not shown). When we analyzed clinicopathological parameters and PI3K levels according to PIK3CA allele distributions in breast cancer patients, the allele frequencies are not associated with neither serum PI3K levels nor prognostic parameters ( $>0.05)$ (Table 5).

\section{Discussion}

Single nucleotide polymorphisms (SNPs) can affect susceptibility to various diseases by altering protein structure

Table 2: Genotypes and allele frequencies for PIK3CA C>A gene polymorphism in $\mathrm{BC}$ cases and controls.

\begin{tabular}{lrrl}
\hline Genotype/Allele & Controls, $\mathbf{n}(\%)$ & Cases, $\mathbf{n}(\%)$ & p-Value \\
\hline CC & $48(47.5)$ & $24(59)$ & 0.129 \\
CA & $46(45.5)$ & $36(39.3)$ & \\
AA & $7(6.9)$ & $1(1.6)$ & \\
C allele & $142(70.29)$ & $84(68.85)$ & $X^{2}=0.075, p=0.783$ \\
A Allele & $60(29.70)$ & $38(31.14)$ & \\
\hline
\end{tabular}

$\mathrm{p}$-Value obtained by chi-square test. 
Table 3: Association of PIK3CA C>A polymorphism with clinicopathological features of $B C$.

\begin{tabular}{|c|c|c|c|c|c|c|c|c|c|}
\hline \multicolumn{2}{|c|}{ Clinicopathological features } & \multicolumn{4}{|c|}{ C allele, \% } & \multicolumn{4}{|c|}{ A allele, $\%$} \\
\hline & & CC + CA & \multirow[t]{2}{*}{ AA } & \multirow[t]{2}{*}{ p-Value } & \multirow{2}{*}{$\begin{array}{r}\text { Odd ratio (OR) } \\
\text { (\%95 Confidence interval) }\end{array}$} & \multirow[t]{2}{*}{$\mathbf{A A}+\mathbf{C A}$} & \multirow[t]{2}{*}{ CC } & \multirow[t]{2}{*}{ p-Value } & \multirow{2}{*}{$\begin{array}{r}\text { Odd ratio (OR) } \\
\text { (\%95 Confidence interval) }\end{array}$} \\
\hline & & & & & & & & & \\
\hline \multirow[t]{2}{*}{ T stage } & $\mathrm{T} 1+\mathrm{T} 2$ & 69.6 & 100 & 1.00 & 1.438 & 68.8 & 75.0 & 1.00 & 1.091 \\
\hline & $\mathrm{T} 3+\mathrm{T} 4$ & 30.4 & - & & $(1.097-1.884)$ & 31.3 & 25.0 & & $(0.649-1.833)$ \\
\hline \multirow[t]{2}{*}{ Distant metastasis } & $(-)$ & 72.2 & 100 & 1.00 & 1.385 & 85.0 & 58.8 & 0.136 & 0.692 \\
\hline & $(+)$ & 27.8 & - & & $(1.131-1.696)$ & 15.0 & 41.2 & & $(0.446-1.073)$ \\
\hline \multirow[t]{2}{*}{ Lymph node status } & No & 41.2 & 100 & 0.429 & 2.429 & 45.0 & 40.0 & 0.767 & 0.889 \\
\hline & $\mathrm{N}+$ & 58.8 & - & & $(1.625-3.629)$ & 55.0 & 60.0 & & $(0.405-1.952)$ \\
\hline \multirow[t]{2}{*}{ Progesterone receptor } & $(-)$ & 23.1 & - & 1.00 & 1.30 & 7.7 & 35.7 & 0.165 & 0.696 \\
\hline & $(+)$ & 76.9 & 100 & & $(1.053-1.605)$ & 92.3 & 64.3 & & $(0.457-1.061)$ \\
\hline \multirow[t]{2}{*}{ Estrogen receptor } & $(-)$ & 9.1 & - & - & - & 5.3 & 14.3 & 0.561 & 0.905 \\
\hline & $(+)$ & 90.9 & - & & & 94.7 & 85.7 & & $(0.713-1.149)$ \\
\hline \multirow[t]{2}{*}{ Tumor necrosis } & $(-)$ & 68.2 & 100 & 1.00 & 1.467 & 75.0 & 57.1 & 0.626 & 0.762 \\
\hline & $(+)$ & 31.8 & - & & $(1.102-1.951)$ & 25.0 & 42.9 & & $(0.378-1.536)$ \\
\hline
\end{tabular}

Table 4: The serum PI3K levels in BC patients and control group.

\begin{tabular}{lrrr}
\hline Study groups & $\mathbf{n}$ & Serum PI3K, ng/mL & p-Value \\
\hline BC patients & 43 & $1.188 \pm 0.743$ & 0.033 \\
Control & 62 & $0.910 \pm 0.574$ & \\
\hline
\end{tabular}

Values are given as mean \pm SD (standard deviation).

and function [31]. Genetic modifications in several signaling pathways such as PI3K/AKT/mTOR induce the cancer risk by promoting critical cellular functions [30]. According to the studies PIK3CA gene mutations in breast cancer are commonly studied worldwide [23, 25, 32, 33]. For instance, Dirican et al. have conducted comprehensive studies about PIK3CA mutations and clinical correlations of PIK3CA gene mutations in breast cancer and they reported 31\% PIK3CA mutation in Turkish BC patients [26].

In current study we focused on PIK3CA rs6443624 gene polymorphism which is the located in intronic region and to the best of our knowledge, this is the first study that analyzed the PIK3CA rs6443624 gene polymorphism in Turkish population. Also we aimed to investigate the possible correlation between serum PI3K levels and clinical, pathological features of the patients according to importance of the PI3K signaling pathway in different types of cancer. There were no significant association between the PIK3CA rs6443624 polymorphism genotype distributions and allele frequency in cases and control groups in our study. Furthermore we did not observe any correlation between PIK3CA rs6443624 genotype distributions, allele frequencies and clinical parameters such as age, family history, smoking status and alcohol consumption also histological parameters ( $p>0.05)$. On the other hand, we found the serum PI3K levels significantly higher in the BC patients compared to the control groups $(\mathrm{p}<0.05)$. Moreover the clinicopathological parameters were analyzed according to PIK3CA rs6443624 allele distributions and PI3K serum levels in cases but the allele frequencies are not associated with neither serum PI3K levels nor prognostic parameters ( $>0.05)$ (Table 5).

There are limited number of studies that subjected directly rs6443624 gene variation in the literature. In a study conducted by Wang et al., they observed the statistically differences in PIK3CA gene variant rs6443624 genotype frequency and allele distributions between $\mathrm{BC}$ patients and control groups in the Chinese population. They found the CC, AC and AA genotypes distribution as

Table 5: PIK3CA:rs6443624 (C>A) polymorphism allele distribution and serum PI3K levels $(\mathrm{ng} / \mathrm{mL})$ in $\mathrm{BC}$ patients and healthy control groups.

\begin{tabular}{|c|c|c|c|c|c|c|}
\hline \multirow[t]{2}{*}{ PI3K genotype } & \multicolumn{3}{|c|}{ Cases $(n=43)$} & \multicolumn{3}{|c|}{ Controls $(n=62)$} \\
\hline & $\mathbf{n}$ & Serum level, $\mathrm{ng} / \mathrm{mL}$ & p-Value & $\mathbf{n}$ & Serum level, $\mathrm{ng} / \mathrm{mL}$ & p-Value \\
\hline AA & - & - & - & 3 & $0.801 \pm 0.072$ & 0.739 \\
\hline$C A+C C$ & 43 & $1.18 \pm 0.74$ & & 59 & $0.91 \pm 0.588$ & \\
\hline $\mathrm{CC}$ & 22 & $1.22 \pm 0.94$ & 0.736 & 34 & $0.858 \pm 0.55$ & 0.440 \\
\hline$C A+A A$ & 21 & $1.14 \pm 0.46$ & & 28 & $0.97 \pm 0.60$ & \\
\hline
\end{tabular}

Values are given as mean \pm SD (standard deviation). 
(24.9, 48.6, and 26.5\%) in healthy controls and (17.7, 45.7, and $36.6 \%$ ) in breast cancer cases, respectively [27]. In our study, CC, AC and AA genotypes distribution in control groups were (47.5, 45.5, and 6.9\%) and in breast cancer patients were $(59,39.3$, and $1.6 \%)$ respectively and we did not observe statistically differences. There are conflicting results in the available literature in terms of prognostic significance of PIK3CA rs6443624 polymorphism. When we performed stratification analyses by regarding prognostic parameters; we did not detect significant correlation between the allele frequencies and histopathological features of patients. However, Wang et al. reported that the PIK3CA polymorphism AC/AA alleles were associated with advanced tumor stage in cases [27]. Bodnar et al. noticed a two-fold increased risk of death in the carriers of the PIK3CA variant A allele compared to individuals with CC genotype in renal cell carcinoma (RCC) [28]. In another study which was performed by Wang LE et al. [34] the risk and clinical outcomes of endometrial cancer were investigated. Their research was included non-Hispanic whites (76.2\%), African Americans (8.7\%), and Mexican Americans $(14.8 \%)$ individuals of endometrial cancer patients. They examined 48 SNPs in their study and followed all cases in terms of death and recurrence after surgical treatment. They found that three SNPs (rs6443624, rs9838411, and rs2699887) in the intron of PIK3CA, were significantly associated with susceptibility and survival or recurrence of endometrial cancer. They concluded that the PIK3CA gene has different effects on the risk and recurrence of endometrial cancer due to its different biological roles in the initiation and progression of endometrial cancer [34]. In contrast Lacey et al., reported no significant relationship between the rs6443624 variant and endometrial cancer in their study which was conducted in Polish population $(\mathrm{p}=0.66)$ [35].

In another study Bizhani et al. investigated PIK3CA, AKT1 and $m T O R$ polymorphisms and they reported a statistical significance between the PIK3CA rs6443624 (C>A) gene variation and the risk of bladder cancer in the Iranian population. According to their result carriers of PIK3CA variant genotype was shown reduced risk of bladder cancer [30].

Wan et al., investigated PIK3CA rs6443624 polymorphism in oral squamous cell carcinoma. They found that the PIK3CA gene expression was significantly higher in tumor tissues, but they did not observe a link between PIK3CA rs6443624 polymorphism and OSCC risk. Furthermore they did not detect differences in the distribution of clinical parameters such as gender, age, and smoking status [36].
Recent studies have reported that PIK3CA can stimulate PIP3 to activate phosphoinositide-dependent kinases PDK1 $(4,9,37)$. AKT is activated after phosphorylation by the PDK1 that contributes the proliferation, survival, metastasis, inhibition of cell apoptosis, and even oncogenic transformation of tumor cells $(4,9,37)$. Hildebrandt et al. investigated the AKT2 rs892119, PIK3CA rs6443624 and PTEN rs12357281 polymorphisms in esophageal cancer patients treated with chemoradiotherapy, and reported that the different recurrence-free survival times might be related with gene-gene interactions [37].

Slattery et al.; investigated several gene $(N F \kappa B 1$, NFKB1A, PTEN, TSC1, TSC2, STK11, RPS6KA2, IKBKB, mTOR, PDK2, PIK3CA, PRKAA1, PRKAG2) variations which play important roles in the regulation of signaling pathways associated with breast cancer pathogenesis. They also analyzed the association between the molecular mechanism of these genes and ethnic differences in cancer risk, they concluded that the differences of breast cancer incidence in various populations might be associated with changes in biological factors [38]. In present study we did not observe any significances between PIK3CA rs6443624 polymorphism and $\mathrm{BC}$ risk and prognosis and our data was consistent with the results of different cancer types in studies that conducted in Chinese [36], Polish [35] populations.

However, our study has limitations for instance the pathogenesis of the disease is complex; this was a preliminary study and the number of the study group was relatively small. Although our research provided a valuable clue for the serum PI3K levels may play a role in BC risk. Larger patient groups data evaluation may have better value in assessment of genetic risk and tumor progression.

\section{Conclusions}

We have concluded that PIK3CA rs6443624 (C>A) gene polymorphism may not have an effective role in the development and tumor progression of $\mathrm{BC}$ in the Turkish population but the PI3K serum levels may related with $\mathrm{BC}$ risk.

Research funding: The present work of Department of Molecular Medicine, The Institute of Health Science, Istanbul University, was supported by a grant from the Scientific Research Projects Coordination Unit of Istanbul University, Project No: 35782.

Conflicts of interest: The authors declare no conflicts of interest. 
Informed consent: Informed consent was obtained. Ethical approval: Ethical approval (Date: 02.09.2020 No: 147435) was obtained from Istanbul University Faculty of Medicine Ethics Committee.

\section{References}

1. Sun YS, Zhao Z, Yang ZN, Xu F, Lu HJ, Zhu ZY, et al. Risk factors and preventions of breast cancer. Int J Biol Sci 2017;13:1387-97.

2. Sever R, Brugge JS. Signal transduction in cancer. Cold Spring Harb Perspect Med 2015;5:a006098.

3. Madsen RR, Vanhaesebroeck B, Semple RK. Cancer-associated PIK3CA mutations in overgrowth disorders. Trends Mol Med 2018; 24:856-70.

4. Yang SX, Polley E, Lipkowitz S. New insights on PI3K/AKT pathway alterations and clinical outcomes in breast cancer. Cancer Treat Rev 2016;45:87-96.

5. Feng Y, Spezia M, Huang S, Yuan C, Zeng Z, Zhang L, et al. Breast cancer development and progression: risk factors, cancer stem cells, signaling pathways, genomics, and molecular pathogenesis. Genes Dis 2018;5:77-106.

6. Zardavas D, Phillips WA, Loi S. PIK3CA mutations in breast cancer: reconciling findings from preclinical and clinical data. Breast Cancer Res 2014;16:1-10.

7. Sobhani N, Roviello G, Corona SP, Scaltriti M, Ianza A, Bortul M, et al. The prognostic value of PI3K mutational status in breast cancer: a meta-analysis. J Cell Biochem 2018;119:4287-92.

8. Arcaro A, Guerreiro AS. The phosphoinositide 3-kinase pathway in human cancer: genetic alterations and therapeutic implications. Curr Genom 2007;8:271-306.

9. Chalhoub N, Baker SJ. PTEN and the PI3-kinase pathway in cancer. Annu Rev Pathol 2009;4:127-50.

10. Vasan N, Toska E, Scaltriti M. Overview of the relevance of PI3K pathway in HR-positive breast cancer. Ann Oncol Off J Eur Soc Med Oncol 2019;30:x3-11.

11. Liu P, Cheng H, Roberts TM, Zhao JJ. Targeting the phosphoinositide 3-kinase pathway in cancer. Nat Rev Drug Discov 2009;8:627-44.

12. Stambolic V, Suzuki A, De la Pompa JL, Brothers GM, Mirtsos C, Sasaki T, et al. Negative regulation of PKB/Akt-dependent cell survival by the tumor suppressor PTEN. Cell 1998;95:29-39.

13. Abraham J. PI3K/AKT/mTOR pathway inhibitors: the ideal combination partners for breast cancer therapies? Expert Rev Anticancer Ther 2014;15:51-68.

14. Jean S, Kiger AA. Classes of phosphoinositide 3-kinases at a glance. J Cell Sci 2014;127:923-8.

15. Vanhaesebroeck B, Guillermet-Guibert J, Graupera M, Bilanges B. The emerging mechanisms of isoform-specific PI3K signalling. Nat Rev Mol Cell Biol 2010;11:329-41.

16. Noorolyai S, Shajari N, Baghbani E, Sadreddini S, Baradaran B. The relation between PI3K/AKT signalling pathway and cancer. Gene 2019;698:120-8.

17. Yang PW, Hsieh MS, Huang YC, Hsieh CY, Chiang TH, Lee JM. Genetic variants of EGF and VEGF predict prognosis of patients with advanced esophageal squamous cell carcinoma. PLoS One 2014;9:e100326.

18. Engelman JA. Targeting PI3K signalling in cancer: opportunities, challenges and limitations. Nat Rev Cancer 2009;9:550-62.

19. Karakas B, Bachman KE, Park BH. Mutation of the PIK3CA oncogene in human cancers. Br J Cancer 2006;94:455-9.

20. Wu G, Xing M, Mambo E, Huang X, Liu J, Guo Z. Somatic mutation and gain of copy number of PIK3CA in human breast cancer. Breast Cancer Res 2005;7:R609-16.

21. Alqahtani A, Ayesh HSK, Halawani H. PIK3CA gene mutations in solid malignancies: association with clinicopathological parameters and prognosis. Cancers (Basel) 2019;12:93.

22. Mukohara T. PI3K mutations in breast cancer: prognostic and therapeutic implications. Breast Cancer (Dove Med Press) 2015;7: 111-23.

23. Millis SZ, Ikeda S, Reddy S, Gatalica Z, Kurzrock R. Landscape of phosphatidylinositol-3-kinase pathway alterations across 19784 diverse solid tumors. JAMA Oncol 2016;2:1565-73.

24. Liu X, Xu Y, Zhou Q, Chen M, Zhang Y, Liang H, et al. PI3K in cancer: its structure, activation modes and role in shaping tumor microenvironment. Future Oncol 2018;14:665-74.

25. Lee JW, Soung YH, Kim SY, Lee HW, Park WS, Nam SW, et al. PIK3CA gene is frequently mutated in breast carcinomas and hepatocellular carcinomas. Oncogene 2005;24:1477-80.

26. Dirican E, Akkiprik M, Özer A. Mutation distributions and clinical correlations of PIK3CA gene mutations in breast cancer. Tumor Biol 2016;37:7033-45.

27. Wang Y, Zhang H, Lin M, Wang Y. Association of FGFR2 and PIK3CA genetic variants with the risk of breast cancer in a Chinese population. Cancer Manag Res 2018;10:1305-11.

28. Bodnar L, Stec R, Cierniak S, Synowiec A, Wcisło G, Jesiotr M, et al. Clinical usefulness of $\mathrm{PI} 3 \mathrm{~K} / \mathrm{Akt} / \mathrm{mTOR}$ genotyping in companion with other clinical variables in metastatic renal cell carcinoma patients treated with everolimus in the second and subsequent lines. Ann Oncol 2015;26:1385-9.

29. Miller SA, Dykes DD, Polesky HF. A simple salting out procedure for extracting DNA from human nucleated cells. Nucleic Acids Res 1988;16:1215.

30. Bizhani F, Hashemi M, Danesh H, Nouralizadeh A, Narouie B, Bahari G, et al. Association between single nucleotide polymorphisms in the $\mathrm{PI} 3 \mathrm{~K} / \mathrm{AKT} / \mathrm{mTOR}$ pathway and bladder cancer risk in a sample of Iranian population. EXCLI J 2018;17: 3-13.

31. Köberle B, Koch B, Fischer BM, Hartwig A. Single nucleotide polymorphisms in DNA repair genes and putative cancer risk. Arch Toxicol 2016;90:2369-88.

32. Thorpe LM, Yuzugullu H, Zhao JJ. PI3K in cancer: divergent roles of isoforms, modes of activation and therapeutic targeting. Nat Rev Cancer 2015;15:7-24.

33. Ahmad F, Badwe A, Verma G, Bhatia S, Das BR. Molecular evaluation of PIK3CA gene mutation in breast cancer: determination of frequency, distribution pattern and its association with clinicopathological findings in Indian patients. Med Oncol 2016;33:74.

34. Wang LE, Ma H, Hale KS, Yin M, Meyer LA, Liu H, et al. Roles of genetic variants in the PI3K and RAS/RAF pathways in 
susceptibility to endometrial cancer and clinical outcomes. J Cancer Res Clin Oncol 2012;138:377-85.

35. Lacey JV, Jr., Yang H, Gaudet MM, Dunning A, Lissowska J, Sherman ME, et al. Endometrial cancer and genetic variation in PTEN, PIK3CA, AKT1, MLH1, and MSH2 within a population-based case-control study. Gynecol Oncol 2011;120:167-73.

36. Wan X, Li X, Yang J, Lv W, Wang Q, Chen Y, et al. Genetic association between PIK3CA gene and oral squamous cell carcinoma: a case control study conducted in Chongqing, China. Int J Clin Exp Pathol 2015;8:13360-6.
37. Hildebrandt MA, Yang H, Hung MC, Izzo JG, Huang M, Lin J, et al. Genetic variations in the PI3K/PTEN/AKT/mTOR pathway are associated with clinical outcomes in esophageal cancer patients treated with chemoradiotherapy. J Clin Oncol 2009;27: 857-71.

38. Slattery ML, John EM, Torres-Mejia G, Lundgreen A, Herrick JS, Baumgartner KB, et al. Genetic variation in genes involved in hormones, inflammation and energetic factors and breast cancer risk in an admixed population. Carcinogenesis 2012;33: 1512-21. 